\title{
Miljøets betydning ved multippel sklerose
}

\begin{abstract}
BAKGRUNN Epidemiologiske studier tyder på at miljøfaktorer spiller en betydelig rolle for utviklingen av multippel sklerose. Vi gir her en oppdatering om miljøets betydning for sykdomsrisiko og sykdomsforløp.
\end{abstract}

KUNNSKAPSGRUNNLAG Vi har gjort litteratursøk i PubMed med søkeordet «multiple sclerosis» kombinert med «environment» samt aktuelle miljøfaktorer.

RESULTATER Det er overveiende sannsynlig at et samspill mellom genetiske og miljømessige faktorer avgjør hvem som utvikler multippel sklerose. Epstein-Barr-virusinfeksjon, røyking og lave nivåer av vitamin D er de miljøfaktorene som har vist sterkest og mest konsistent assosiasjon med utvikling av sykdommen. Lavt vitamin D-nivå er også forbundet med høy sykdomsaktivitet. Andre aktuelle risikofaktorer er overvekt og høyt saltinntak.

FORTOLKNING Selv om man i epidemiologiske studier har identifisert en rekke potensielle etiologiske miljøfaktorer og betydningen av disse støttes av eksperimentelle studier, er det fortsatt ikke tilstrekkelige holdepunkter for å fastslå at de spiller en kausal rolle.

Forekomsten av multippel sklerose er økende, og det er beregnet at om lag 10000 mennesker i Norge har sykdommen (1). Multippel sklerose reduserer livslengden med 5-10 år og er en hyppig årsak til nevrologisk invaliditet. Til tross for bedret behandling er det derfor fortsatt behov for kunnskap som kan bidra til å forebygge sykdommen.

Forskning innen epidemiologi, genetikk og immunologi har gitt økt innsikt i hvilke faktorer som kan forårsake multippel sklerose. Målet med denne artikkelen er å drøfte miljøets betydning for sykdomsrisiko og sykdomsprogrediering.

\section{Kunnskapsgrunnlag}

Artikkelen bygger på utvalgte engelskspråklige original- og oversiktsartikler, identifisert ved litteratursøk i PubMed med søkeordet «multiple sclerosis» kombinert med «environment» (1 523 treff), «vitamin D» (760 treff), «EBV» (317 treff), «Epstein-Barr virus» (544 treff), «smoking» (336 treff), «nicotine» (21 treff), «cotinine» (5 treff), «vitamin A» (47 treff), «retinol» (53 treff), «sodium» (398 treff), «body mass» (188 treff) og «obesity» (139 treff). Søket ble avsluttet i september 2014.

Vårt samlede kunnskapsgrunnlag er bygd opp gjennom flere års interesse og arbeid på området. Overskrifter og sammendrag er gjennomgått, og et flertall av artiklene er vurdert i fulltekst. For vurdering av epidemiologisk evidens har vi særlig lagt vekt på prospektive kohortstudier og store pasientkontroll-studier. Ved vurdering av betydning for sykdomsforløpet har vi vektlagt intervensjonsstudier og observasjonelle studier ut fra metodologisk kvalitet.

Vi har lagt vekt på systematiske oversikter over behandlingseffekter og vurdert originalartiklene som disse bygger på. Der hvor kliniske studier er oppsummert i metodologisk gode systematiske oversikter, er sistnevnte valgt som referanse. For virkningsmekanismer er studier med humane data prioritert samt in vivo-studier i dyremodeller som vi mener er særlig relevante.

\section{Arv og miljø}

Arvbarhet er et mål på andelen av variasjon i en egenskap i en populasjon som skyldes genetisk variasjon. Arvbarheten for multippel sklerose varierer i studier mellom $25 \%$ og $76 \%$ (2). Store genomvide assosiasjonsstudier har avdekket at variasjon i mer enn 100 gener bidrar til sykdomsrisikoen (3). Det er imidlertid vist at det er en beskjeden risikoøkning når det gjelder hver enkelt kjent genvariant eller miljøfaktor. Mange argumenterer derfor for at det må være interaksjoner mellom gener og miljøfaktorer (4).

Det er for eksempel vist at røyking og overvekt har størst betydning for risikoen for multippel sklerose hos bærere av HLAgener som disponerer for sykdommen $(5,6)$. HLA-genene spiller en viktig rolle i immunforsvaret, og et slikt funn kan tyde på at overvekt og røyking øker risikoen gjennom å påvirke immunsystemet. Én mulig forbindelse mellom gener og miljø er epigenetikk, der miljøfaktorer påvirker genuttrykket uten å endre nukleotidsekvensen i DNAstrengen.

Biologiske søsken til personer med multippel sklerose har økt sykdomsrisiko, mens adopterte søsken har samme risiko som resten av befolkningen (7). Dette indikerer at miljøfaktorene ved multippel sklerose ikke selektivt rammer de som blir syke, men er utbredt der sykdommen er vanlig. Slike faktorer kan være vanskelige å oppdage, fordi de fleste som ikke blir syke også har vært eksponert.

\author{
Kristin Ingeleiv Løken-Amsrud \\ kristin.ingeleiv.loken@gmail.com \\ Nevrologisk avdeling \\ Sykehuset Innlandet Lillehammer
}

\section{Andreas Lossius}

Avdeling for immunologi og transfusjonsmedisin Oslo universitetssykehus, Rikshospitalet

\section{Øivind Torkildsen}

Nevrologisk avdeling

Haukeland universitetssykehus og

KG Jebsen senter for MS-forskning

Klinisk institutt 1

Universitetet i Bergen

\section{Trygve Holmøy}

Nevroklinikken

Akershus universitetssykehus

Institutt for klinisk medisin

Universitetet i Oslo

ID Engelsk oversettelse på www.tidsskriftet.no

\section{HOVEDBUDSKAP}

Forekomsten av multippel sklerose er økende, både i Norge og i de fleste vestlige land

$\emptyset$ kningen skyldes sannsynligvis endret eksponering for miljøfaktorer

Epstein-Barr-virus, røyking og mangel på vitamin $D$ er de miljøfaktorene som er sterkest assosiert med risiko for å utvikle sykdommen 


\section{Utbredelse}

Prevalensen av multippel sklerose er lav rundt ekvator og øker med økende breddegrad, også etter justering for den sterkeste genetiske risikofaktoren for sykdommen HLA-DRB1*1501-allelet (8). Data fra Europa (9) og Nord-Amerika (10) tyder imidlertid på at denne gradienten avtar på grunn av økende insidens i sør. Slike epidemiologiske forandringer kan indikere endret eksponering for miljøfaktorer. Et annet eksempel på dette er en økning av andelen kvinner som får multippel sklerose (11).

I studier fra ulike land har man funnet at de som er født om våren, har litt høyere risiko for multippel sklerose enn de som er født om høsten (12). Dette kan tyde på at miljøfaktorene virker svært tidlig i livet og er relatert til årstid, slik som infeksjonssykdommer og sollys. Disse studiene er blitt kritisert for at man ikke har justert for fødselsår og fødested (13). Vi fant imidlertid fortsatt signifikant overhyppighet av fødselstidspunkt i april hos pasienter med multippel sklerose etter justering for disse faktorene (14).

Studier har vist at migrasjon fra områder med høy til lav forekomst er forbundet med redusert sykdomsrisiko (15), særlig dersom flyttingen skjer i barndommen og tidlige ungdomsår. Migranter som returnerte til de vestindiske øyer etter å ha bodd i Frankrike, hadde økt sykdomsrisiko, spesielt hvis de returnerte før fylte 15 år (16). Tilsvarende viste en studie i Oslo at multippel sklerose var hyppigere hos innvandrere fra Midtøsten og Asia enn det sykdomsforekomsten i disse landene skulle tilsi (17). Selv om slike studier er beheftet med usikkerhetsmomenter knyttet til forskjeller i diagnostikk og at emigranter utgjør en selektert gruppe, tyder migrasjonsstudiene samlet på betydningen av miljøfaktorer tidlig i livet.

\section{Utvalgte miljøfaktorer}

Epstein-Barr-virus

Til tross for at gjennomgått Epstein-Barrvirusinfeksjon er meget vanlig i den generelle voksne befolkningen (90-95\%), er dette viruset sterkt assosiert med utvikling av multippel sklerose (18). Tilnærmet alle voksne pasienter med sykdommen har gjennomgått en slik virusinfeksjon, og en prospektiv studie viste at dette skjer før debut av symptomer på multippel sklerose (19). Gjennomgått infeksjon øker også risikoen for multippel sklerose hos barn, men ikke alle barn med sykdommen er seropositive for Epstein-Barr-virus (20). Infeksjonen er derfor neppe nødvendig for å utvikle multippel sklerose.

To forhold tyder på at ungdomsårene er den viktigste sårbarhetsperioden for EpsteinBarr-viruseksponering: I områder hvor pri-

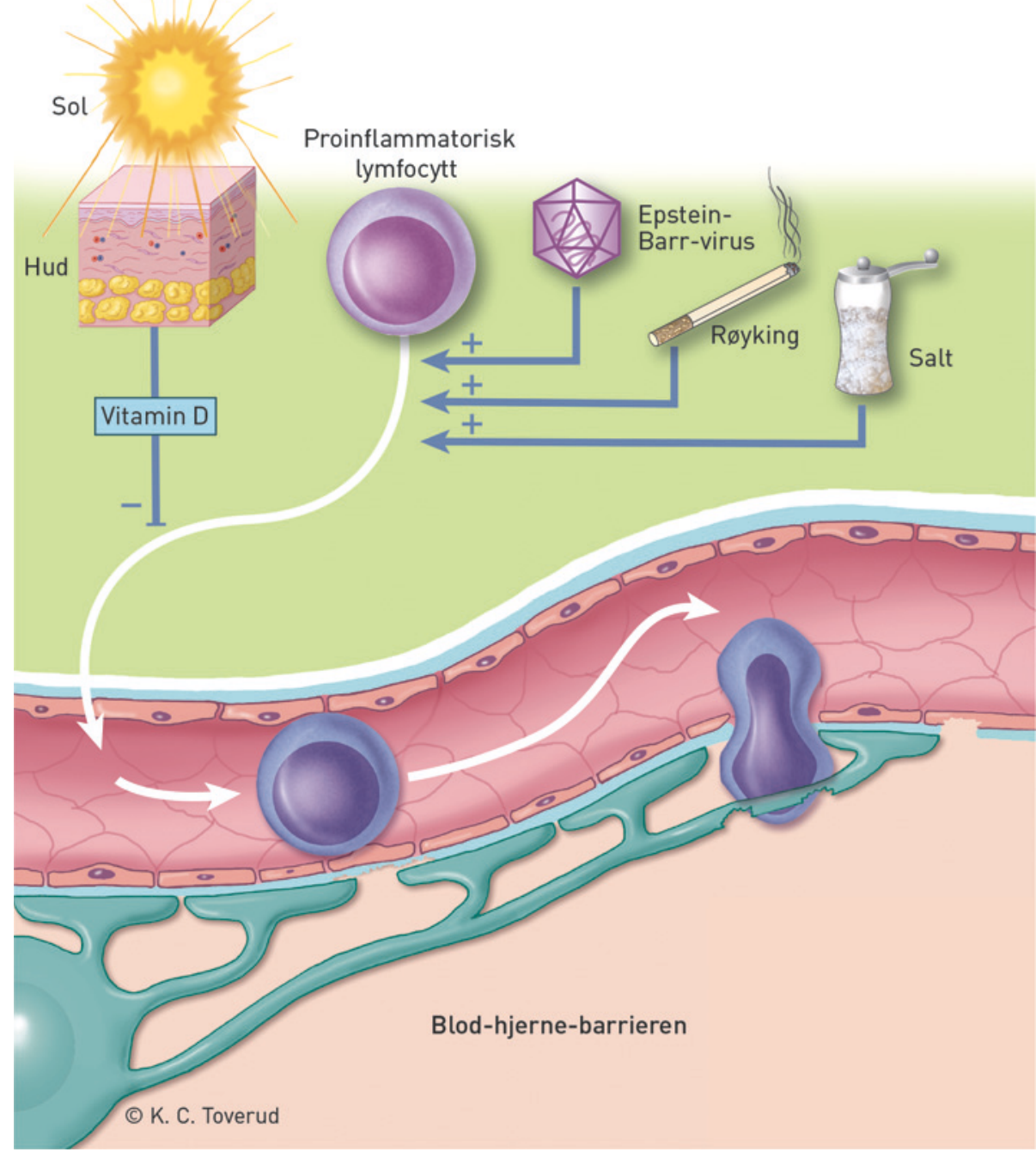

Figur 1 En forenklet oversikt over Epstein-Barr-virus, røyking og vitamin D som miljøfaktorer ved utviklingen av multippel sklerose. Mulige mekanismer: Sykdomsprosessen drives av migrasjon av proinflammatoriske lymfocytter (T-og B-celler) til hjerne og ryggmarg (markert med pill. Epstein-Barr-virus og røyking aktiverer proinflammatoriske lymfocytter og bidrar dermed til økt migrasjon av slike celler til hjernen. Vitamin D hemmer migrasjon av lymfocytter til hjernen ved å stimulere regulatoriske $T$-celler. Ved overvekt akkumuleres vitamin D i fettvevet, slik at det blir lavere nivåer tilgjengelig for immunsystemet

mær infeksjon skjer tidlig, er forekomsten av multippel sklerose lav, og infeksiøs mononukleose, som skyldes primær Epstein-Barrvirusinfeksjon i ungdomsårene, dobler risikoen for multippel sklerose (18).

Mulige mekanismer for Epstein-Barrvirusinfeksjon ved multippel sklerose inkluderer immunologisk kryssreaksjon, at viruset beskytter autoreaktive B-celler mot apoptose samt aktivering av autoreaktive T-celler ved overskytende immunreaksjoner mot EpsteinBarr-virus (18). I tråd med en immunologisk mekanisme ser det ut til at T-celler rettet mot viruset akkumuleres i spinalvæsken hos personer med multippel sklerose (21). I to studier fant man Epstein-Barr-virusinfiserte Bceller i hjernevev fra avdøde som hadde hatt multippel sklerose $(22,23)$. Imidlertid har dette vært vanskelig å reprodusere (24), og det ser heller ikke ut til å være spesifikt for multippel sklerose (23).

\section{Røyking}

En rekke epidemiologiske studier tyder på at røyking dobler risikoen for multippel sklerose (25), med en dose-respons-sammenheng for kumulativ røykedose (26). Økningen i sykdomsrisiko er også bekreftet ved at forhøyede nivåer av kotinin (en surrogatmarkør for nikotin) ble målt i blodprøver tatt før utvikling av multippel sklerose (27). Nikotin per se er imidlertid neppe en viktig patogen faktor, da bruk av snus ikke ser ut til å øke risikoen (28) og fordi nikotin beskytter mot utvikling av multippel sklerose-liknende sykdom hos mus (29). Sårbarhetsperioden for røyking er ikke avklart. I en studie var det ingen alderspåvirkning (26), mens en 
Tabell 1 Foreslåtte miljøfaktorer ved multippel sklerose. Holdepunkter for årsakssammenheng vurdert ut fra momenter foreslått av Hill (53) (se ramme 1). Etter forfatternes vurdering: +: Gjennomførte studier forenlig med Hills synspunkt. -: Ikke tilstrekkelig holdepunkt fra gjennomførte studier eller ingen tilgjengelige studier

\begin{tabular}{|c|c|c|c|c|c|c|}
\hline Hill & $\begin{array}{c}\text { Epstein- } \\
\text { Barr- } \\
\text { virus }\end{array}$ & Røyking & $\begin{array}{l}\text { Vitamin } \\
\text { D }\end{array}$ & Overvekt & $\begin{array}{l}\text { Vitamin } \\
\text { A }\end{array}$ & Saltinntak \\
\hline Styrke & + & - & - & - & - & - \\
\hline Konsistens & + & + & + & + & - & - \\
\hline Tidssammenheng ${ }^{1}$ & + & + & + & + & - & - \\
\hline Biologisk gradient & - & + & + & - & - & - \\
\hline Biologisk rasjonale & + & + & + & + & + & + \\
\hline Koherens & + & + & + & + & + & + \\
\hline Randomisert studie & - & - & - & - & - & - \\
\hline
\end{tabular}

Vurdering av tidssammenheng er basert på prospektive studier, men tidssammenheng er vanskelig å vurdere ved multippel sklerose fordi man ikke vet når den biologiske sykdomsprosessen starter

annen indikerte økt sårbarhet i ungdomsår/ ung voksen alder (27).

Effekten av røyking på sykdomsaktiviteten er ikke klar. Det er rapportert at røyking er forbundet med hurtigere overgang fra første symptom til sikker multippel sklerose (30), raskere funksjonsnedsettelse (31) og økt sykdomsaktivitet målt med MR-undersøkelse (32). En metaanalyse viste imidlertid kun grensesignifikant assosiasjon til sykdomsprogrediering (25).

Mulige mekanismer for røyking inkluderer toksisk effekt på nevroner og oligodendrocytter og aktivering av encefalittogene lymfocytter i lungene (33).

\section{Vitamin D}

Hypotesen om at det er en sammenheng mellom vitamin $\mathrm{D}$ og multippel sklerose stammer fra observasjonen om et inverst forhold mellom sykdomsforekomst og sollysets intensitet (34). Vitamin D-hypotesen støttes av en rekke in vitro-studier og dyremodellstudier, som har vist at aktivt vitamin D (1,25-dihydroksyvitamin $\mathrm{D} / \mathrm{kalsitriol}$ ) induserer antiinflammatoriske immunceller, inkludert regulatoriske T-celler (35).

En prospektiv helseundersøkelse blant amerikanske sykepleiere viste at hos dem som tok kosttilskudd med over 400 internasjonale enheter (IE) vitamin D per dag, var risikoen for multippel sklerose $40 \%$ lavere enn hos dem som ikke brukte tilskudd (36). I en annen stor prospektiv amerikansk helseundersøkelse hadde den femdelen av deltakerne som hadde høyest vitamin D-nivå (>99 nmol/l) $60 \%$ lavere risiko for multippel sklerose enn de med lavest nivå $(<63 \mathrm{nmol} / \mathrm{l})$ (37). Tilsvarende resultater er funnet i Sverige (38).

Prospektive studier tyder også på at økende nivåer av vitamin $\mathrm{D}$ er forbundet med lav risiko for sykdomsattakk (39) og lav sykdomsaktivitet vist ved MR-undersøkelse (40) samt lavere risiko for utvikling av multippel sklerose etter første kliniske tegn på demyeliniserende sykdom (41).

\section{Andre faktorer}

Sollys kan ha immunmodulerende egenskaper uavhengig av vitamin D (42). Epidemiologiske studier indikerer at liten soleksponering kan være en selvstendig risikofaktor for multippel sklerose (43-45). Det er derfor vanskelig å avgrense effekten av vitamin D fra andre effekter av sollys.

Som for andre immunmedierte sykdommer er det foreslått at tidlig eksponering for mange mikrober beskytter mot utvikling av multippel sklerose senere i livet. Denne såkalte hygienehypotesen er forenlig med at insidensen av sykdommen er lavere i utviklingsland enn i land med bedre sosioøkonomiske forhold (46), men dette er det vanskelig å verifisere i studier.

Overvekt før voksen alder er assosiert med økt risiko for multippel sklerose (47, 48). Overvekt medfører både lavere sirkulerende vitamin D-verdier på grunn av økt distribusjon i fettvevet og høyere serumnivåer av proinflammatoriske cytokiner (særlig interleukin-6 og tumornekrosefaktor-alfa), som begge kan tenkes å bidra til den økte risikoen.

Vitamin A har immunregulerende egenskaper som kan være relevante ved multippel sklerose. En prospektiv studie viste at intermediære nivåer av retinolbindende protein (surrogatmarkør for vitamin A) var assosiert med lav sykdomsrisiko (49). Vi fant at økende nivåer av retinol var assosiert med lav risiko for sykdomsaktivitet vist ved MR-undersøkelse (50).
RAMME 1

Epidemiologen sir Austin Bradford Hill foreslo i 1965 å vektlegge følgende momenter ved vurdering av årsakssammenheng (53)

- Assosiasjonens styrke - en svak assosiasjon utelukker ikke kausal sammenheng. men jo sterkere assosiasjon, desto mer sannsynlig er en årsakssammenheng

- Konsistens - sammenfallende funn i ulike populasjoner ut fra ulike studiedesigner i ulike situasjoner

- Spesifisitet - årsakssammenheng er mer sannsynlig hvis en bestemt eksposisjon gir ett spesifikt utfall, hvilket innen medisinen er svært sjelden ${ }^{1}$

- Tidssammenheng - eksposisjon må ha forekommet før sykdomsprosessen starter

- Biologisk gradient - økende grad av eksponering gir økende insidens av eller risiko for sykdom eller raskere sykdomsutvikling og vice versa ved inverse assosiasjoner

- Biologisk rasjonale - en biologisk plausibel sammenheng øker sannsynligheten for kausal sammenheng. Imidlertid vil dette momentet begrenses av den til enhver tid etablerte kunnskap

- Koherens - en eventuell årsakssammenheng skal ikke stå i motsetning til etablert kunnskap. Sammenfallende funn i epidemiologiske studier og laboratoriefors $\emptyset \mathrm{k}$ styrker antakelsen om årsakssammenheng

- Eksperiment - utvikles sykdom etter tilføring av eksponeringsfaktoren eller forhindres sykdom etter fjerning av eksposisjonen? I vår situasjon vil eksperimentet være en (randomisert) klinisk studie

- Analogi - liknende effekt av liknende eksponeringsfaktorer ${ }^{1}$

${ }^{1}$ Momentene spesifisitet og analogi vektlegges av mange i mindre grad, så også av sir Austin Bradford Hill.

Det ble nylig vist at mus som spiste mye salt, utviklet en mer aggressiv multippel sklerose-liknende sykdom enn mus som fikk lite salt (51) samt at pasienter med multippel sklerose med høyt saltinntak hadde betydelig høyere sykdomsaktivitet enn pasienter med lavt inntak (52). Høyt saltinntak hos mus stimulerte Th17-celler, som er involvert i flere autoimmune sykdommer (51).

\section{Diskusjon}

Assosiasjon er ikke ensbetydende med kausalitet. I tabell 1 er elementer som taler for kausalitet for foreslåtte miljøfaktorer sammenfattet, vurdert ut fra et sett av momenter som ofte brukes for dette formålet (ramme 1) (53). 
Det mest tungtveiende momentet - effekt på sykdomsrisiko i en randomisert studie - er ikke testet for noen miljøfaktor når det gjelder multippel sklerose. Primærprofylakse er komplisert fordi sykdommen er sjelden og multifaktoriell og fordi det sannsynligvis kan gå svært lang tid mellom eksponering og symptomdebut. Mens tiltak mot røyking vil være utelukkende helsefremmende, vil tiltak rettet mot Epstein-Barr-virus og vitamin D også kunne ha utilsiktede negative helseeffekter og i studier kreve svært store grupper og lang oppfølgingstid med både positive og negative utfallsmål. Ut fra konsistente funn $\mathrm{i}$ epidemiologiske og eksperimentelle studier mener likevel enkelte epidemiologer at Epstein-Barr-virus, vitamin D og røyking er kausale faktorer (54).

Det er betydelig interesse for vitamin D som sekundærprofylakse ved multippel sklerose. Flere pilotstudier uten tilstrekkelig styrke til å avklare sammenheng mellom intervensjon og endepunkt er utført, og i en metaanalyse ble det nylig konkludert med at høydose vitamin D-tilskudd ikke har noen effekt på sykdomsaktiviteten (55).

I henhold til dagens kunnskap vil vi ikke anbefale store doser vitamin D ved multippel sklerose. Pasientene har imidlertid ofte vitamin D-verdier som er suboptimale for beinhelsen - de utvikler tidlig osteopeni og har $ø$ kt risiko for beinbrudd $(56,57)$. I gjentatte målinger av vitamin D-nivå hos 88 norske personer med sykdommen fant vi at de fleste hadde serumnivåer under offisielle anbefalinger $(50 \mathrm{nmol} / \mathrm{l})$ gjennom store deler av året (58).

Ut fra det som er kjent om effekten av tilskudd på serumnivået, har vi beregnet at et moderat tilskudd av 800 IE $(20 \mu \mathrm{g})$ vitamin $\mathrm{D}_{3}$ daglig ville gitt nesten alle et akseptabelt nivå (> $50 \mathrm{nmol} / \mathrm{l})$ hele året og et nivå som er assosiert med lav sykdomsaktivitet (75-125 $\mathrm{nmol} / \mathrm{l}$ ) mesteparten av året (58). Vi vil derfor anbefale tilskudd av om lag 800 IE til personer med multippel sklerose. Alternativt kan konsentrasjonen av 25-hydroksyvitamin D i serum måles og nivåer mellom $75 \mathrm{nmol} / \mathrm{log}$ $125 \mathrm{nmol} / 1$ tilstrebes.

\section{Kristin Ingeleiv Løken-Amsrud (f. 1979)}

har en ph.d.-grad på emnet fettløselige vitaminer og multippel sklerose. Hun er lege i spesialisering og forsker

Forfatter har fylt ut ICMJE-skjemaet og oppgir ingen interessekonflikter.

\section{Andreas Lossius (f. 1979)}

har en ph.d.-grad på emnet miljøfaktorer ved multippel sklerose. Han har en postdoktorstilling.

Forfatter har fylt ut ICMJE-skjemaet og oppgir ingen interessekonflikter.

\section{Øivind Torkildsen (f. 1979)}

er ph.d., postdoktor, lege i spesialisering og professor

Forfatter har fylt ut ICMJE-skjemaet og oppgir ingen interessekonflikter.

\section{Trygve Holmøy (f. 1960)}

er spesialist i nevrologi og overlege. Han er også professor og klinikkleder.

Forfatter har fylt ut ICMJE-skjemaet og oppgir ingen interessekonflikter.

\section{Litteratur}

1. Berg-Hansen P, Moen SM, Harbo HF et al. High prevalence and no latitude gradient of multiple sclerosis in Norway. Mult Scler 2014; 20: 1780-2.

2. Hawkes $\mathrm{CH}$, Macgregor AJ. Twin studies and the heritability of MS: a conclusion. Mult Scler 2009; 15. $661-7$.

3. Beecham AH, Patsopoulos NA, Xifara DK et al. Analysis of immune-related loci identifies 48 new susceptibility variants for multiple sclerosis. Nat Genet 2013: 45: 1353-60.

4. Lin R, Charlesworth J, van der Mei I et al. The genetics of multiple sclerosis. Pract Neurol 2012 12: $279-88$.

5. Hedström AK, Lima Bomfim I, Barcellos L et al. Interaction between adolescent obesity and HLA risk genes in the etiology of multiple sclerosis. Neurology 2014; 82: 865-72

6. Hedström AK, Sundqvist E, Bäärnhielm M et al. Smoking and two human leukocyte antigen genes interact to increase the risk for multiple sclerosis. Brain 2011; 134: 653-64.

7. Ebers GC, Sadovnick AD, Risch NJ. A genetic basis for familial aggregation in multiple sclerosis. Nature 1995: 377: 150 -1.

8. Simpson S Jr, Blizzard L, Otahal P et al. Latitude is significantly associated with the prevalence of multiple sclerosis: a meta-analysis. J Neurol Neurosurg Psychiatry 2011: 82: 1132-41.

9. Koch-Henriksen N, Sorensen PS. Why does the north-south gradient of incidence of multiple scle rosis seem to have disappeared on the northern hemisphere? J Neurol Sci 2011; 311: 58-63.

10. Hernán MA, Olek MJ, Ascherio A. Geographic variation of MS incidence in two prospective studies of US women. Neurology 1999; 53: 1711-8.

11. Koch-Henriksen N, Sørensen PS. The changing demographic pattern of multiple sclerosis epidemiology. Lancet Neurol 2010: 9: 520-32.

12. Ramagopalan SVD, Link J, Byrnes JKP et al. HLA-DRB1 and month of birth in multiple sclerosis. Neurology 2009; 73: 2107-11

13. Fiddes B, Wason J, Kemppinen A et al. Confounding underlies the apparent month of birth effect in multiple sclerosis. Ann Neurol 2013; 73: $714-20$

14. Torkildsen O, Aarseth J, Benjaminsen E et al. Month of birth and risk of multiple sclerosis: confounding and adjustments. Ann Clin Transl Neurol 2014; 1: 141-4

15. Gale CR, Martyn CN. Migrant studies in multiple sclerosis. Prog Neurobiol 1995; 47: 425-48.

16. Cabre $P$, Signate $A$, Olindo $S$ et al. Role of return migration in the emergence of multiple sclerosis in the French West Indies. Brain 2005; 128: 2899-910.

17. Smestad C. Sandvik L, Holmoy T et al. Marked differences in prevalence of multiple sclerosis between ethnic groups in Oslo, Norway. J Neurol 2008; 255: 49-55

18. Lossius A, Johansen JN, Torkildsen $\emptyset$ et al. Epstein-Barr virus in systemic lupus erythematosus, rheumatoid arthritis and multiple sclerosis association and causation. Viruses 2012; 4 $3701-30$

19. Levin LI, Munger KL, O'Reilly EJ et al. Primary infection with the Epstein-Barr virus and risk of multiple sclerosis. Ann Neurol 2010; 67: 824-30
20. Banwell B, Bar-Or A, Arnold DL et al. Clinical, environmental, and genetic determinants of multiple sclerosis in children with acute demyelination: a prospective national cohort study. Lancet Neurol 2011; 10: 436-45.

21. Lossius A, Johansen JN, Vartdal F et al. Highthroughput sequencing of TCR repertoires in multiple sclerosis reveals intrathecal enrichment of EBV-reactive CD8+ T cells. Eur J Immunol 2014 44: $3439-52$

22. Serafini B, Rosicarelli B, Franciotta D et al. Dysregulated Epstein-Barr virus infection in the multiple sclerosis brain. J Exp Med 2007; 204: 2899-912

23. Tzartos JS, Khan G, Vossenkamper A et al. Association of innate immune activation with latent Epstein-Barr virus in active MS lesions. Neurology 2012; 78: 15-23.

24. Torkildsen $\emptyset$. Stansberg C, Angelskår SM et al. Upregulation of immunoglobulin-related genes in cortical sections from multiple sclerosis patients. Brain Pathol 2010; 20: 720-9.

25. Handel AE, Williamson AJ, Disanto G et al. Smoking and multiple sclerosis: an updated metaanalysis. PLoS ONE 2011; 6: e16149.

26. Hedström AK, Hillert J, Olsson T et al. Smoking and multiple sclerosis susceptibility. Eur J Epidemiol 2013; 28: 867-74

27. Salzer J, Hallmans G, Nyström M et al. Smoking as a risk factor for multiple sclerosis. Mult Scler 2013; 19: 1022-7.

28. Hedström AK, Hillert J, Olsson T et al. Nicotine might have a protective effect in the etiology of multiple sclerosis. Mult Scler 2013; 19: 1009-13.

29. Naddafi F, Reza Haidari M, Azizi G et al. Novel therapeutic approach by nicotine in experimental model of multiple sclerosis. Innov Clin Neurosci 2013; 10: $20-5$.

30. Di Pauli F, Reindl M, Ehling R et al. Smoking is a risk factor for early conversion to clinically definite multiple sclerosis. Mult Scler 2008; 14: 1026-30.

31. Manouchehrinia A, Tench CR, Maxted J et al. Tobacco smoking and disability progression in multiple sclerosis: United Kingdom cohort study. Brain 2013; 136: 2298-304.

32. Healy BC, Ali EN, Guttmann CR et al. Smoking and disease progression in multiple sclerosis. Arch Neurol 2009: 66: 858-64

33. Odoardi F. Sie C, Streyl K et al. T cells become licensed in the lung to enter the central nervous system. Nature 2012; 488: 675-9.

34. Goldberg P. Multiple sclerosis: vitamin D and calcium as environmental determinants of prevalence (a viewpoint) Part 1: sunlight, dietary factors and epidemiology. Int J Environ Stud 1974; 6: 19-27.

35. Smolders J, Damoiseaux J. Vitamin D as a T-cell modulator in multiple sclerosis. Vitam Horm 2011 86: $401-28$

36. Munger KL, Zhang SM, O'Reilly E et al. Vitamin D intake and incidence of multiple sclerosis. Neurology 2004: 62: 60-5

37. Munger KL, Levin LI, Hollis BW et al. Serum 25 -hydroxyvitamin $D$ levels and risk of multiple sclerosis. JAMA 2006; 296: 2832-8.

38. Salzer J, Hallmans G, Nyström M et al. Vitamin D as a protective factor in multiple sclerosis. Neurology 2012; 79: $2140-5$

39. Simpson S jr., Taylor B, Blizzard L et al. Higher 25-hydroxyvitamin D is associated with lower relapse risk in multiple sclerosis. Ann Neurol 2010; 68: 193-203.

40. Mowry EM, Waubant E, McCulloch CE et al. Vitamin D status predicts new brain magnetic resonance imaging activity in multiple sclerosis. Ann Neurol 2012: 72: 234-40.

41. Ascherio A, Munger KL, White R et al. Vitamin D as an early predictor of multiple sclerosis activity and progression. JAMA Neurol 2014; 71: 306-14.

42. Becklund BR, Severson KS, Vang SV et al. UV radiation suppresses experimental autoimmune encephalomyelitis independent of vitamin D production. Proc Natl Acad Sci U S A 2010; 107 6418-23 
43. Bäärnhielm M, Hedström AK, Kockum I et al. Sunlight is associated with decreased multiple sclerosis risk: no interaction with human leukocyte antigen-DRB1*15. Eur J Neurol 2012; 19: 955-62.

44. Lucas RM, Ponsonby AL, Dear K et al. Sun exposure and vitamin D are independent risk factors for CNS demyelination. Neurology 2011; 76: 540-8.

45. Zivadinov R, Treu CN, Weinstock-Guttman B et al. Interdependence and contributions of sun exposure and vitamin D to MRI measures in multiple sclerosis. J Neurol Neurosurg Psychiatry 2013: 84: 1075-81.

46. Fleming J, Fabry Z. The hygiene hypothesis and multiple sclerosis. Ann Neurol 2007; 61: 85-9.

47. Munger KL, Bentzen J, Laursen B et al. Childhood body mass index and multiple sclerosis risk: a long-term cohort study. Mult Scler 2013; 19 ; 1323-9.

48. Langer-Gould A, Brara SM, Beaber BE et al. Child hood obesity and risk of pediatric multiple sclerosis and clinically isolated syndrome. Neurology 2013; 80: 548-52

49. Salzer J, Hallmans G, Nyström M et al. Vitamin $A$ and systemic inflammation as protective factors in multiple sclerosis. Mult Scler 2013; 19: 1046-51.

50. Løken-Amsrud KI, Myhr KM, Bakke SJ et al. Retinol levels are associated with magnetic resonance imaging outcomes in multiple sclerosis. Mult Scler 2013; 19: $451-7$

51. Kleinewietfeld M, Manzel A, Titze J et al. Sodium chloride drives autoimmune disease by the induction of pathogenic TH17 cells. Nature 2013; 496 : $518-22$.

52. Farez MF, Fiol MP, Gaitán MI et al. Sodium intake is associated with increased disease activity in multiple sclerosis. J Neurol Neurosurg Psychiatry 2015; 86: 26-31

53. Hill AB. The Environment and disease: association or causation? Proc R Soc Med 1965; 58: 295-300.

54. Ascherio A. Environmental factors in multiple sclerosis. Expert Rev Neurother 2013; 13 (suppl) 3-9.

55. James E, Dobson R, Kuhle J et al. The effect of vitamin D-related interventions on multiple sclerosis relapses: a meta-analysis. Mult Scler 2013; 19: $1571-9$

56. Moen SM, Celius EG, Sandvik L et al. Low bone mass in newly diagnosed multiple sclerosis and clinically isolated syndrome. Neurology 2011; 77 $151-7$.

57. Bazelier MT, van Staa TP, Uitdehaag BM et al. Risk of fractures in patients with multiple sclerosis: a population-based cohort study. Neurology 2012; 78: $1967-73$

58. Holmøy T, Torkildsen $\emptyset$, Myhr KM et al. Vitamin D supplementation and monitoring in multiple sclerosis: who, when and wherefore. Acta Neurol Scand Suppl 2012; 126: 63-9.

Mottatt 11.6. 2014, første revisjon innsendt 27.6. 2014, godkjent 12.3. 2015. Redaktør: Trine B. Haugen.

\section{Spiriva «Boehringer Ingelheim}

Antikolinergikum. ATC-nr.: RO3B Bo

C T

政 um $2,5 \mu \mathrm{g}$, benzalkoniumklorid, dinatriumedetat, saltsyre, van Indikasjoner: Kols. Bronkodilaterende vedtikeholdsbehandling for a tindre symimptomer hos pasienter med kronisk obstruktiv lungesyklikeholdsbehandling hos voksne med astma som blir behandlet med vedlikeholdskombinasjonen av inhalasjonskortikosteroider ( $2800 \mu \mathrm{g}$ budesonid/dag eller tilsvarende) og langtidsvirkende be ta2-agonister og som har hatt en eller flere alvorlige eksaserbas.
joner det siste arret. Dosering: Voksne: 2 inhalasioner (a $2.5 \mu \mathrm{g})$ joner det siste aret. Dosering: Voksne: 2 inhalasjoner (a 2,5 $\mathrm{\mu g}$ ) gang pr. døgn, til samme tid hver dag. Anbefalt dosering bor ikke overskrides. Ved astma vil full nytteverdi oppnàs etter flere dose sikkerhet ved astma og cystisk fibrose er ikke etablert. Administre ring: Kun til inhalasjon. Inhaleres vha. Respimat inhalator. Kontraindikasjoner: Overfølsomhet for tiotropiumbromid, atropin eller dets derivater, f.eks. ipratropium eller oxitropium, eller for noen as mid skal ikke brukes til innledende behandling av akutte episoder av bronkospasme eller for lindring av akutte symptomer. Ved akutte anfall bør en hurtigvirkende betaz-agonist benyttes. Bør ikke

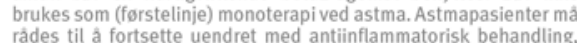
rådes til ă fortsette uendret med antiinflammatorisk behandling, dvs. inhalerte kortikosteroider, etter at de har startet med Spiriva
inhalasjonsvæske, selv om symptomene deres forbedres. Akutte inhalasjonsvæske, selv om symptomene deres forbedres. Akutte
hypersensitivitetsreaksjoner kan forekomme etter inhalasjon av preparatet. Brukes med forsiktighet hos pasienter med trangvinkelglaukom, prostatahyperplasi eller blærehalsobstruksjon. bronkospasme. Spiriva inhalasjonswaske bor brukes med forsiktighet ved kjent hjerterytmeforstyrrelse. Hos pasienter med moderat til alvorlig nedsatt nyrefunksjon (kreatininclearance $550 \mathrm{ml}$

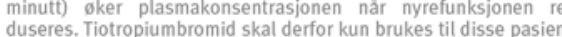
tene hvis den forventede nytten av behandlingen oppveier den potensielle risikoen. Pasientene bør advares mot à fá oppløsningen øynene. Dette kan utløse eller forverre trangvinkelglaukom, gi øyesmerter eller ubehag, forbigående tákesyn, halo eller farge fenomen sammen med røde øyne som følge av økt blodtilførsel konjunktiva eller ødem i cornea. Hvis symptomer pâ trangvinkel glaukom skulle oppstă, skal pasienten slutte ả bruke tiotropiumvert ved antikolinerg behandling, kan over lengre tid forårsake karies. Tiotropiumbromid skal ikke brukes oftere enn 1 gang $p$ døgn. Preparatet er ikke anbefalt ved cystisk fibrose (CF). Bruk kan øke tegn og symptomer på CF (f.eks. alvorlige bivirkninger, pulmonære eksaserbasjoner, luftveisinfeksjoner). Svimmelhet eller
tăkesyn kan pảvirke evnen til â kiøre bil eller bruke maskiner. Intertákesyn kan pâvirke evnen til â kjøre bil eller bruke maskiner. Inter-
aksjoner: Samtidig administrering av tiotropiumbromid og andre antikolinerge legemidler er ikke undersokt og anbefales derfor ikke. Graviditet, amming og fertilitet: Graviditet: Kliniske data of begrenset. Det anbefales à unngá bruk under graviditet. Amming ikke ved amming hvis ikke den forventede nytten av behandlinge oppveier den eventuelle risikoen for det nyfødte barnet. Fertilitet: Ingen tilgjengelige data. Bivirkninger: Mange av bivirkningene kar tilskrives preparatets antikolinerge egenskaper. Kols: Vanlige $(\geq 1 / 100$ til <1/10): Gastrointestinale: Munntørrhet. Mindre vanlige ( $21 / 1000$ til <1/100): Gastrointestinale: Forstoppelse, orofarynga candidiasis, dysfagi. Hjerte/kar: Atrieflimmer, palpitasjoner, takykardi (inkl. supraventrikulær takykardi). Hud: Hudutslett, kløe. Luft veier: Hoste, epistakse, faryngitt, dysfoni. Nevrologiske: Svimme het, hodepine. Nyre/urinveier: Urinretensjon, dysuri. Sjeldne ( $\geq 1 / 10$ 000 til <1/1000): Gastrointestinale: Gastroøsofageal reflukssyhdom, karies, gingivitt, glossitt, stomatitt. Hud: Angioødem, urticargitt. Nyre/urinveier: Urinveisinfeksjon. Øye: Glaukom, øk intraokulært trykk, tåkesyn. Ukjent frekvens: Gastrointestinale: Intestinal obstruksjon, inkl. paralytisk ileus, kvalme. Hud: Anafylaktisk reaksjon, hypersensitivitet (inkl. straksreaksjoner). Luftveier:
Sinusitt. Muskel-skjelettsystemet: Hovne ledd. Nevrologiske: Sinusitt. Muskel-skjelettsystemet: Hovne ledd. Nevrologiske: Søvnløshet. Stoffskifte/ernæring: Dehydrering. Astma: Vanlige
$(\geq 1 / 100$ til $<1 / 10)$ : Gastrointestinale: Munntørrhet. Mindre vanlige ( $21 / 1000$ til $<1 / 100)$ : Gastrointestinale: Orofaryngal candidiasis. Hjerte/kar: Palpitasjoner. Luftveier: Hoste, faryngitt, dysfon. Sjeldne (at/10 000 til $<1 / 1000)$; Gastrointestinale: forstoppelse, gingivitt, stomatitt. Hud: Hudutslett, kløe, angioødem, urticaria, hypersensitivitet (inkl. straksreaksjoner). Ukjent frekvens: Gastrointestinale: Dysfagi, gastroøsofageal reflukssykdom, karies, glos sitt, intestinal obstruksjon, inkl. paralytisk ileus, kvalme. Hjerte kudinfeksion/hudsâr, torr hud, anafylaktisk reaksion. Luftveier: Epistakse, laryngitt, sinusitt. Muskel-skielettsystemet: Hovne led Nyre/urinveier: Urinretensjon, dysuri, urinveisinfeksjon. Stoffskifte/ernæring: Dehydrering. Øye: Glaukom, økt intraokulær trykk, tåkesyn. økt antikolinerg effekt kan forekomme med økend alder. Overdosering/Forgiftning: Høye doser tiotropiumbromid kan føre til antikolinerge tegn og symptomer. Akutt forgiftning ved utilsik-
tet oralt inntak av tiotropiumbromid inhalasjonsvæske er usannsynlis pga. lav oral biotilgjengelighet. Se Giftinformasjonens anbefalinger Ro3B B04 side d. Egenskaper: Klassifisering: Langtidsvirkende spe. sifikk muskarinreseptorantagonist. Virkningsmekanisme: Tiotropi-
umbromid bindes til de muskarine reseptorene i bronkienes glatte umbromid bindes til de muskarine reseptorene i bronkienes glatte muskulatur, og hemmer de kolinerge effektene (bronkokonstriks.
jon) av acetylkolin. I luftveiene vises en selektiv, kompetitiv og rejon) av acetylkolin. I luftveiene vises en selektiv, kompetitiv og re-
versibel antagonisme til M3-reseptorene, som fører til relaksering. Effekten er doseavhengig og varer $\mathrm{i}$ mer enn 24 timer. Den langvarige effekten skyldes sannsynligvis den langsomme frisetselektivt ved inhalasjon. Tiotropiumbromid, gitt 1 gang daglig, gir en signifikant bedring i lungefunksjonen ( $F E V_{1}$ og FVC) innen 30 minutter etter første dose. Ingen tegn til toleranseutvikling er se ved bruk over en ettársperiode. Dyspné bedres signifikant. En sig. nifikant redusert risiko for eksaserbasjoner er vist. Absorpsjon: C. nâr systemisk sirkulasjon. Lav absorpsion fra mage-tarmkanalen (10-15\%). Maks. plasmakonsentrasjon oppnás etter 10 minutter Proteinbinding: $72 \%$. Fordeling: Distribusjonsvolum: 32 liter $/ \mathrm{ks}$.
Halveringstid: Den terminale eliminasjonshalveringstiden etter in-

Boehringer Ingelheim Postboks 405, 1373 Asker, Tlf 66761300 Faks 66902533 halasjon er 5.6 dager. Total clearance: $880 \mathrm{mt} /$ minutt. Metabo lisme: Metaboliseres $i$ liten grad. Esteren av tiotropiumbromid gjenP.450 (CYP 2 D6 0 Og $_{3} \mathrm{~A}_{4}$ ) er involvert i metabolismen av en mindre del av dosen. Utskillelse: $20-30 \%$ via urin, resten via feces. Oppbevaring og holdbarhet: Má ikke fryses. Holdbarhet etter anbrudd: 3 Pakninger os priser: 60 doser (1 pastron + Respimat inhal bruk. mnd forbruk) kr 452,00 Refusjon:Astma: Refusion iht paragrafene $3 a$ i HELFO eller 5,22 i folketrygdloven: $\$ 3$ a: Dersom et legemiddel ikke kan skrives direkte pă bla resept etter $\$ 2$, kan legen pà vegge av bruker søke HELFO om individuell refusjon etter $\$ 3$ a. \$ 5,22: Det kan ytes bidrag til dekning av utgifter for legemidler som ikke dekkes pliktmessig etter folketrygdlovens $\$ 5.14$ (blà resept). Kols: Refusion ytes kun til pasienter med moderat til alvorlig KOLS (FEV Refusjon ytes kun til pasienter med moderat til alvorlig KOLS (FEV struktiv lungesykdom ICD. J44. Annen kronisk obstruktiv lungesykdom ICD. J43 Emfysem. Vilkâr 90: Diagnosen má være verifisert ved Sist endret: 22 .

\section{Striverdi «Boehringer Ingelheimn}

C Adrenergikum. ATC-nr.: R03A C 19

INHALASJONSVAESKE, oppløsning 2,5 $\mu \mathrm{g} /$ dose i Respimat inhalator: Hver dose inneh.: Olodaterolhydroklorid tilsv. olodaterol 2, ug, benzatkoniumklorid, dinatriumedetat, sitronsyre, renset vann. enter med kronisk obstruktiv lungesykdom (kols). Dosering: Voksne: 2 inhalasjoner (à $2,5 \mu \mathrm{g}) 1$ gang pr. døgn, til samme tid hver dag. er ikke relevant Administrering: Kun til inhag ungdom $<18$ arr: Bruk Respimat inhalator. Kontraindikasioner: Overfolsombet for noen av innholdsstoffene. Forsikttighetsregler: Bor ikke brukes ved astma da effekt og sikkerhet ved langvarig bruk ved astma ikke er undersøkt. Bor ikke brukes til innledende behandling av akutt bronkospasme, f.eks, til behovsbehandling. Akutt hypersensitivitetsreaksjon kan forekomme etter inhalasjon. Legemidler som inhaleres kan forá sake paradoksal bronkospasme som kan være livstruende. Beinnledes. Bør brukes med forsiktighet ved kient kardiovaskular sykdom, særlig iskemisk hjertesykdom, alvorlig dekompensert hjertesvikt, hjertearytmi, hypertrofisk obstruktiv kardiomyopath. brukes med forsiktighet ved krampesykdom, tyreotoksikose os ved uvanlig sterk respons pá sympatomimetiske aminer. Erfaring ved nylig hjerteinfarkt, nylig sykehusinnleggelse pga. hjertesvikt, ustabil eller livstruende hjertearytmi eller paroksysmal takykardi er begrenset, og preparatet bør brukes med forsiktighet. Kan gi klinisk signifikant kardiovaskulær effekt hos enkelte, mâlt som økning hjertefrekvens, blodtrykk og/eller symptomer. Sepo nering bør vur om er en potensiell risikofaktor for utvikling av kardiovaskulære bivirkninger. Ved alvorlig kols kan dette forsterkes av hypoksi og eg oke faren for hiertearytmi. Inhalasjon au hoye doser kan fore ti økt glukosenivá i plasma. Forsiktighet bor utvises ved planlagte op erasioner der det skal brukes halogenert hydrokarbon som anestesi, da det er okt risiko for bivirkninger av betagonister Svimmelehet kan pâvirke evnen til a kiøre bil eller bruke maskinter. Interaksioner Samtidig administrering av andre adrenerge preparater (alene eller Samtidig administrering av andre adrenerge preparater (alene elle behandling med xantinderivater, steroider eller ikke-kaliumsparende diuretika kan forsterke hypokalemisk effekt av olodaterol. Effekten av olodaterol kan hemmes eller blokkeres av betablokkere (inkl. oyedraper), og bor kun brukes sammen med disse dersom betydelig forsiktighet bør vurderes i slike tilfeller. Effekten av olodaterol pá det kardiovaskulære systemet kan forsterkes av MAO-hemmere, TCA eller andre legemidler som kan forlenge QTC-intervallet. Samtidis administrering av ketokonazol, en potent P.gp- og CYP.hemmer, øker systemisk eksponering av olodaterol med $70 \%$. Ingen dosejustering er nødvendig. Graviditet, amming og fertilitet: Graviditet: Kliniske data mangler. Bruk under graviditet bør unngås. Amming: Ukjent on olodaterol gár over i morsmelk. Anbefales ikke ved amming. FertilHet: Ingen data. Bivirkninger: Mindre vanlige ( $(21 / 1000$ til $<1 / 100)$;
Hud: Utslett. Infeksiøse: Nasofaryngitt. Nevrologiske: Svimmelhet. Sjeldne ( $21 / 10$ ooo til <1/1000): Hjerte/kar: Hypertensjon. MuskeSkelettsystemet: Leddsmerter. Bivirkninger rapportert med andre er: Takykardi, arytmier, palpitasjoner, myokardial iskem angina pectoris, hypertensjon, hypotensjon, skjelving, hodepine, sykdomsfølelse, hypokalemi, hyperglykemi og metabolsk acidose. Overdosering/Forgiftning: Symptomer: Sannsynligvis forsterkning av bivirkninger typiske for beta2-agonister. Behandling: Støttende og symptomatisk. Alvorlige tilfeller bor innlegges pá sykehus. Kardioselektive betablokkere kan brukes, men med forsiktighet, pga. risiko for bronkospasme. Egenskaper: Klassifisering: Selektiv beta2-agonist. Virkningsmekanisme: Aktivering av beta2-adrenerge reseptorer fører til forhøyet nivã av CAMP, som induserer bronkieuCmax nâs a relaksere glatt muskulatur i luftveiene. Absorpsjon: gjengelighet er $30 \%$. Proteinbinding: Ca. $60 \%$ (in vitro). Fordeling: Distribusjonsvolum: 1110 liter, som tyder pă stor vevsdistribusjon. Halveringstid: Olodaterol plasmakonsentrasjon etter inhalasjon har en multifasisk nedgang, med en terminal halveringstid pả ca. 45 timer. Metabolisme: Hovedsakelig ved direkte glukuronidering og 0-demetylering, etterfulgt av konjugering. Utskillelse: $>90 \%$ av dosen utskilles innen 5-6 dager etter oral eller i.v. administrering, uendret $i$ urin ved steady state. Oppbevaring og holdbarhet: Má ikke fryses. Holdbarhet etter anbrudd: 3 mâneder. Respimat inhalator skat kastes etter 3 maneders bruk. Pakninger og priser: 60 doser sbehandling ved symptomer pá bronkoobstruksjon hos pasienter med kronisk obstruktiy lungesykdom (KOLS). Refusjonskoder: ICPC: R95 Kronisk obstruktiv lungesykdom. ICD: 143 Emfysem I 44 Annen kronisk obstruktiv lungesykdom. Vilkăr 90 : Refusion ytes kun til pasienter med etablert KOLS. - Diagnosen má være verifisert ved spirometri. Hvis spirometri ikke kan giennomføres, má ärsaken journalføres. Vilkăr 9 : Refusjon ytes kun til pasienter med moderat eller alvorlig KOLS (FEV $1<80 \%$ av forventet verdi). 